УдК 341.4

DOI https://doi.org/10.32837/apdp.v0i85.1823

Н. А. Галабурда

\title{
ІМПЛЕМЕНТАЦІЯ МІЖНАРОДНИХ КРИМІНАЛЬНО-ПРОЦЕСУАЛЬНИХ НОРМ ЯК ФОРМА ВПЛИВУ МІЖНАРОДНОГО ПРАВА НА НАЦІОНАЛЬНЕ ПРАВО
}

Постановка проблеми. В сучасних умовах протидія міжнародній злочинності вимагає не лише об'єднання зусиль держав, але й ефективного впровадження норм міжнародного кримінального права в національне законодавство. У зв'язку з цим особливого значення набуває така форма впливу міжнародного права на національне як імплементація. В той же час нині немає одностайності у доктрині міжнародного права щодо її розуміння. Ця обставина, а також практична відсутність наукових досліджень проблем імплементації міжнародних кримінально-правових норм в Україні й визначають актуальність і необхідність цієї статті.

Аналіз останніх досліджень і публікацій. Необхідно наголосити, що раніше в Україні наукові дослідження в сфері імплементації міжнародних кримінально-правових норм як форм впливу міжнародного права на національне право практично не здійснювалися. Проте теоретичні основи взаємодії міжнародного й національного права досліджували такі українські вчені-міжнародники як В.Г. Буткевич [7]. Окремі аспекти цієї проблеми досліджувалися зарубіжними вченими А.Г. Кібальник [1], В.А. Батир [2], А.Л. Лучініним [3], Р.А. Мюллерсоном [4], В.А. Вдовіним [6], N. Kimmo [9].

Основною метою статті є дослідження особливостей імплементації міжнародних кримінально-правових норм як форми впливу міжнародного права на національне право; аналіз основних доктринальних підходів вчених щодо визначення поняття «імплементація» і відмежування його від інших подібних понять.

Виклад основного матеріалу. Насамперед слід зазначити, що термін «імплементація» (від лат. “impliko" - «наповнюю», «виконую» чи англ. “implementation”«здійснення», «виконання») у доктрині міжнародного права та в теорії зазвичай означає процес здійснення, а точніше реалізації положень міжнародних угод як на міжнародному рівні, так і в рамках національної юрисдикції [1, с. 188]. Попри різні доктринальні підходи до визначення поняття «імплементація» найбільш точним слід вважати визначення національно-правової імплементації як процесу, що припускає реалізацію норм міжнародного кримінального права на території держави у сфері дії внутрішньодержавного права за його допомогою і відповідно до визначеної процедури, забезпеченої організаційно-правовою діяльністю органів держави, спрямованою на фактичне виконання прийнятих державою міжнародних зобов'язань [2, с. 7]. Обгрунтованою є думка А.Л. Лучініна про те, що поняття «імплементація» не є синонімом до поняття «виконання», оскільки імплементація - це процес, тоді як виконання - можливий результат цього процесу [3, с. 25-26].

(c) Н. А. Галабурда, 2020 
Справедливим є й зауваження Р.А. Мюллерсона про те, що національно-правова імплементація відбувається навіть тоді, коли держава перед тим, як стати учасником міжнародного договору, щоб уникнути конфліктів договору з нормами національного права, вносить певні зміни у своє право [4, с. 75].

Для того, щоб з'ясувати особливості імплементації як форми впливу міжнародного кримінального права на національне кримінальне право, спочатку необхідно проаналізувати й інші форми такого впливу. Так, О.Н. Шібков виділяє такі форми впливу міжнародного кримінального права на кримінальне право: посилання, рецепція, імплементація, які є видами інкорпорації. При імплементації відбувається не буквальне включення положень міжнародної норми в національний закон, а адаптація вже наявної кримінально-правової норми або нової норми кримінального закону національним законодавцем відповідно до особливостей правової системи держави [5, с. 74].

Можна погодитися з критичною оцінкою підходів О.Н. Шібкова, А.Г. Кібальника, описаних упраціВ.А. Вдовіна[6, с. 73-74], бонормакримінальногоправанеможе включати акт міжнародного права. Інша точка зору, тобто визнання міжнародного праваджереломнаціональногоправаірозглядпитаннязпозиціймонізму, помилкова.

Низка дослідників, використовуючи підхід, розроблений В.Г. Буткевичем [7, с. 32], пропонують виділяти не форми, прийоми чи способи національно-правової імплементації, а процедури узгодження внутрішньодержавних правових актів 3 міжнародно-правовими приписами як процес імплементації, відносячи до неї посилання, паралельну правотворчість, уніфікацію, перетворення, створення спеціального правового режиму, скасування внутрішньодержавних актів, які суперечать міжнародним зобов'язанням. Підхід цей є суперечливим, оскільки узгодження є процесом упорядкування норм, а ще подоланням протиріч, колізій, цільове ж призначення національно-правової імплементації полягає в реалізації положень «міжнародного кримінального законодавства» на внутрішньодержавному рівні, а не в уніфікуванні норм міжнародного та національного кримінального права [8, с. 10].

Деякі дослідники пропонують відмовитися від використання термінів «інкорпорація», «трансформація» через їхню невідповідність явищам, які вони позначають, не визнають рецепцію як спосіб імплементації щодо міжнародних угод, які стосуються кримінально-правових питань. Аргументом проти рецепції вважають вказівку на те, що цей процес добровільний і односторонній та, на відміну від імплементації, не передбачає участі держави у створенні рецептивних правових норм, виконання міжнародних зобов'язань [6, с. 71].

Не погоджуючись із подібними аргументами, необхідно зазначити, що держава може приєднатися до вже укладених міжнародних угод, у розробленні тексту яких вона участі не брала, але це не означає, що процес не залежить від волі держави і не забезпечується її правовими та організаційними засобами. Має йтися, мабуть, не про однобічність процесу рецепції, а про спрощений спосіб національно-правової імплементації, яким не передбачені зміни чинного законодавства, а зводять їх до проведення процедур ратифікації, опублікування, необхідних для надання юридичної сили тексту міжнародної угоди в рамках національної юрисдикції. На думку фінського юриста М. Шейніна, подібний прийом національно-правової імпле- 
ментації можна позначити терміном «транскрипція» (transcription) [9, с. 327]. Я погоджуюся з цією думкою, оскільки запропонований термін фактично відображає суть прийому рецепції, яка полягає в текстуальному відтворенні положень міжнародної угоди.

Розглядаючи системно процес взаємодії міжнародного та національного кримінального права, визначаючи загальні умови ефективності національно-правової імплементації, необхідно звернути увагу на той факт, що, крім збереження внутрішньої стійкості і стабільності розвитку кримінально-правової системи, вона постійно відчуває потребу у зовнішньому впливі, який, провокуючи конструктивну дезорганізацію або перенастроювання національної системи, підвищує її функціональні якості. Відомі приклади довільного трактування норм міжнародних угод з боку законодавця, що призводить до появи в кримінальному законодавстві норм, за якими вузько означені політичні завдання, тобто до деформації взаємодії міжнародного та національного кримінального права [10, с. 14].

Щодо позначення різних форм впливу міжнародного права на національне право слід зауважити й те, що у спеціальних дослідженнях це називається способами національно-правової імплементації, при яких використовують різні терміни: «трансформація» (Д.Б. Левін [11, с. 247], А.С. Гавердовський [12, с. 82]); «спеціальна трансформація» (Є.Т. Усенко [13, с. 16]); «адаптація» (А.П. Спірідонов [14, с. 126]), «імплементація» (А.Г. Кібальник [1, с. 188]) або ж загальний термін не використовують взагалі (В.А. Вдовін [6, с. 108]).

Фахівці підтримують різні теорії (теорію трансформації, теорію імплементації), внаслідок чого єдиний підхід до умовного позначення конкретного способу національно-правової імплементації не вироблено. Однак спроби систематизувати або впорядкувати таку термінологію на базі накопиченого теоретичного матеріалу дають досить суперечливі результати. Так, А.П. Спірідонов у своїй праці вводить нове трактування способу адаптації, розуміючи його не як пристосування чинних внутрішньодержавних норм до нових міжнародних зобов'язань без зміни законодавства, як пропонує В.А. Вдовін, або ж як сприйняття положень міжнародного права чинним законодавством, яке не потребує зміни кримінального закону, а зовсім інакше.

Фактично адаптацію А.П. Спірідонов розглядає як прийом, коли «конструювання нових норм або редагування вже наявних відбувається у повній відповідності до особливостей правової системи держави» [14, с. 127], що «забезпечує дотримання цілей тієї чи іншої міжнародної норми, а також її змісту при збереженні можливостей національної нормотворчої лексики, прийомів законодавчої техніки, інших традицій національного нормотворення» .

Такий підхід є необгрунтованим, адже автор не підтверджує власну позицію про те, що адаптація - основний прийом імплементації. Зауважу, що адаптація в ïi первісному розумінні, тобто як спосіб національно-правової імплементації, не передбачає зміни внутрішньодержавного законодавства при реалізації положень міжнародних актів, не настільки широко використовується. Тому позиція А.П. Спірідонова дещо помилкова, а нове трактування адаптації практично не обгрунтоване. Вважаю справедливими критичні зауваження А.М. Аверкова [15, с. 247], 
В.Я. Суворової [16, с. 247], Ю.В. Трунцевського [17, с. 247] про те, що термін «трансформація» спотворює розуміння суті цього способу національно-правової імплементації - норми однієї системи не можуть перетворитися на норми іншої.

Щоб використовувати синонім критикованого терміну «трансформація», необхідно пояснити, що при використанні терміну «перетворення» характеризується процес, який відбувається саме у внутрішньодержавному законодавстві при реалізації міжнародних норм. Хоча міжнародні норми не змінюють своєї юридичної природи, структури та змісту, а перетворення, яке може включати скасування раніше чинних законів, їхнє доповнення або зміну, прийняття нових законів (наприклад, Кодекс злочинів проти міжнародного права, прийнятий у 2002 році в ФРН) відбувається саме в національному законодавстві. Переналаштування законодавства, проведене з урахуванням його особливостей під впливом імпульсів із зовнішнього середовища, тобто вже прийнятих державою міжнародних зобов'язань, або в рамках підготовки приєднання до міжнародних угод, сприяє його вдосконаленню[13, с. 21].

Найбільш поширеним способом національно-правової імплементації, щодо якого в юридичній науці практично не проводять дискусій, є посилання. Під «посиланням» розуміють спосіб національно-правової імплементації, коли безпосередньо в текст національного закону включаються положення, що зобов'язують правозастосувача обов'язково звертати увагу на норми міжнародного права та застосовувати їх, хоча сам текст таких норм міжнародної угоди в тексті закону не відтворюють. Б.Л. Зимненко заперечує можливість безпосереднього застосування за певних умов і навіть з санкції держави норм міжнародного права у внутрішньодержавній сфері і вважає, що при використанні інкорпораційного посилання застосовують не міжнародну, а комплексну норму, що утворюється при включенні окремих положень міжнародного права у правову систему країни, і поєднання таких положень із положеннями внутрішньодержавних правових джерел [18, с. 106-108].

Така позиція є спірною, оскільки відома практика безпосереднього застосування міжнародних угод. Конвенцію Ради Свропи про захист прав людини й основні свободи 1950 року, а також інші міжнародні договори, норми яких відносять до самовиконуючих, застосовують безпосередньо, вони не потребують прийняття внутрішньодержавного законодавства для цілей їхньої реалізації.

Здебільшого в конституціях держав містяться положення, які є прикладом загальної відсильної норми, санкціонуючи застосування норм міжнародної угоди, обов'язкових для держави, належним чином ратифікованих і опублікованих (ст. 55 Конституції Франції), або ж загальновизнаних принципів і норм міжнародного права (ст. 25 Основного закону ФРН), або ж визначають місце міжнародних актів в рамках правової системи конкретної держави (п. 2 ст. VI Конституції США).

Крім загальних посилань, законодавець у галузевому законодавстві використовує спеціальні. Наприклад, у німецькому Кодексі злочинів проти міжнародного права 2002 року є спеціальні відсильні норми: у п. 6 § Кодексу зазначено, що під особами, яких охороняють відповідно до міжнародного гуманітарного права під час міжнародного збройного конфлікту або у не міжнародному збройному конфлікті, потрібно розуміти осіб, перелічених у Женевських конвенціях 1949 року і Додатковому протоколі I 1977 року [19]. У цьому контексті варто погодитися з дум- 
кою Б.Л. Зимненко про те, що не завжди закони, які вводять нові склади злочинів, містять посилання на міжнародні акти, навіть коли саме вони зумовили їхне прийняття, хоча це необхідно для правильного та ефективного застосування нових кримінально-правових норм [18, с. 19].

Висновки. Можна зробити висновок, що основною метою імплементації як кримінальних процесуальних, так і міжнародних кримінально-правових норм як форм впливу міжнародного права на національне право є зміна чинного законодавства на виконання міжнародних зобов'язань з урахуванням особливостей кримінально-правової системи, структури чинного галузевого законодавства, особливостей законодавчої техніки. Це дає змогу законодавцю виконати завдання щодо реалізації положень міжнародної угоди й підвищити якість законодавства, причому положення норм міжнародного кримінального права є імпульсом, який ініціює перегляд положень національного законодавства у випадках, коли це прямо передбачено в тексті міжнародної угоди або вимагається згідно із законом. На ефективність імплементації безпосередньо впливає якість національного законодавства, а також вибір законодавцем способів імплементації: рецепції, адаптації, перетворення і відсилання.

\section{Jimepamypa}

1. Кибальник А.Г. Сучасне міжнародне кримінальне право: поняття, завдання та принципи / А.Г. Кибальник. СПб. : Изд-во «Юридичний центр Пресс», 2003. С. 188.

2. Батир В.А. Імплементація норм міжнародного гуманітарного права / В.А. Батир. Мінск. : Гендальф, 2000. С. 7.

3. Лучинин А.Л. Особливості механізму імплементації європейського права : дис. канд. юрид. наук. К, 2006. С. 25-26.

4. Мюллерсон Р.А. Співвідношення міжнародного і національного права / Р.А. Мюллерсон. К. : Міжнародні відносини, 1982. С. 74.

5. Шибко О.Н. Принципи і норми міжнародного права як джерела кримінального права : дис. ... канд. юрид. наук. С., 2000. С. 41.

6. Вдовін В.А. Імплементація міжнародно-правових норм у кримінальному праві: питання Загальної частини) / В.А. Вдовін, 2006. С. 73-74.

7. Буткевич В.Г. Теоретичні основи взаємодії міжнародного і внутрішньодержавного права : автореф. дис. ... докт. юрид. наук. К., 1980. С. 32.

8. Бичковський А.П. Узгодження норм міжнародного і внутрішньодержавного права : автореф. дис. докт. юрид. наук. К., 1986. С. 10.

9. Kimmo N. Transforming International Law and Obligations into Finnish Criminal Legislation // Finnish Yearbook of International Law. Vol. X. Kluwer Law International, 2002. P. 327.

10. Волкогон Т.А. Про критерії ефективності системи права / Т.А. Волкогон // Ефективність законодавства і сучасні юридичні технологи: матер. засід. Міжн. школи-практикуму молодих вчених-юристів (29-30 травня 2008 року) / відп. ред. Т.Я. Хабрієва. М., 2009. С. 14-16.

11. Левін Д.Б. Актуальні проблеми теорії міжнародного права / Д.Б. Левін. К., 1974. С. 247.

12. Гавердовский А.С. Імплементація норм міжнародного права / А.С. Гавердовский. К. : Вища школа, 1980. С. 82.

13. Усенко Є.Т. Співвідношення і взаємодія міжнародного і національного права та Конституції України / Е.Т. Усенко // Журнал міжнародного права. 1995. № 2. С. 13-29.

14. Спиридонов А.П. Адаптація - прийом імплементації норм міжнародного кримінального права в білоруське кримінальне право / А.П. Спиридонов // Еволюція державних і правових інститутів в сучасній Белорусії: вчені записки. Вип. III. Мінськ, 2005. С. 123-126.

15. Аверков В.М. Теоретичні проблеми уніфікації / В.М. Аверков // Мінський журнал міжнародного права. 2000. № 3. С. 74. 
16. Суворова В.Я. Реалізація норм міжнародного права / В.Я. Суворова. Мінск, 1992. С. 19.

17. Трунцевскій Ю.В. Про оцінку ролі міжнародного кримінального права в національному законодавстві в умовах глобалізації / Ю.В. Трунцевскій // Наукові основи кримінального права і процеси глобалізації : матер. V МІЖНАРОДНОГО конгресу кримінального права (27-28 травня 2010 року). К. : Проспект, 2010. С. 211.

18. Зимненко Б.Л. Про застосування норм міжнародного права судами загальної юрисдикції : [довідковий посібник] / Б.Л. Зимненко: Статут; РАП, 2006. 539 с.

19. Текст Закону про введення в дію Кодексу злочинів проти міжнародного права від 26.07.2002. [Електронний ресурс]. Режим доступу: http://www.iuscomp.org/gla/statutes/Voe StGB.pdf.

\section{Анотація}

Галабурда Н. А. Імплементація міжнародних кримінально-процесуальних норм як форма впливу міжнародного права на національне право. - Стаття.

у статті досліджуються особливості імплементації міжнародних кримінально-процесуальних та кримінально-правових норм як форми впливу міжнародного права на національне право. Аналізуються основні доктринальні підходи вчених до визначення поняття «імплементація» і відмежування його від інших подібних понять. Виявляється специфіка впливу правових норм міжнародних конвенцій на правові норми кримінального права окремих держав.

Можна зробити висновок, що основною метою реалізації як кримінального процесуального, так і міжнародного кримінального права як форми впливу міжнародного права на національне право є зміна чинного законодавства для виконання міжнародних зобов'язань з урахуванням кримінально-правової системи, структури чинного галузевого законодавства, законодавчої техніки.

Це дозволяє законодавцю реалізувати положення міжнародної угоди та покращити якість законодавства, а положення міжнародного кримінального права є поштовхом, який ініціює перегляд національного законодавства у випадках, коли це прямо передбачено в тексті міжнародної угоди або вимагається законом. На ефективність реалізації безпосередньо впливає якість національного законодавства, а також вибір законодавцем методів реалізації: прийому, адаптації, трансформації та направлення.

Незважаючи на різні доктринальні підходи до визначення поняття «імплементація», найбільш точним слід вважати визначення національної правової імплементації як процесу, що передбачає реалізацію міжнародного кримінального права в державі у сфері внутрішнього права з його допомогою та зі встановленим порядком; юридична діяльність державних органів, спрямована на фактичне виконання міжнародних зобов'язань, взятих на себе державою. Підтримую думку А.Л. Лучиніна про те, що поняття "реалізація» не є синонімом поняття «виконання», оскільки реалізація - це процес, а виконання - можливий результат цього процесу.

Конвенція Ради Європи про захист прав людини і основоположних свобод 1950 року, а також інші міжнародні договори, норми яких стосуються самореалізації, безпосередньо застосовуються, вони не потребують прийняття внутрішнього законодавства для їх реалізації. Зазвичай у конституціях держав містяться положення, які є прикладом загального довідкового правила, що дозволяють застосовувати міжнародні угоди, обов'язкові для держави, належним чином ратифіковані та опубліковані, або загальновизнаних принципів і норм міжнародного права, або визначають місце міжнародного права в межах правової системи конкретної держави.

Ключові слова: імплементація, форма впливу, міжнародні кримінальні правові та процесуальні норми, міжнародне право, національне право України.

\section{Summary}

Halaburda $N$. A. Implementation of international criminal procedures as a form of influence of international law on national law. - Article.

It can be concluded that the main purpose of the implementation of both criminal procedural and international criminal law as a form of influence of international law on national law is to change the current legislation to meet international obligations taking into account the criminal law system, the structure of current sectoral legislation, legislative technique.

This allows the legislator to implement the provisions of the international agreement and improve the quality of legislation, and the provisions of international criminal law are the impetus that initiates the revision of national legislation in cases where it is expressly provided in the text of the international agreement or required by law. The effectiveness of implementation is directly affected by the quality of national legislation, as well as the legislator's choice of methods of implementation: reception, adaptation, transformation and referral. 
Despite the different doctrinal approaches to the definition of "implementation", the most accurate should be considered the definition of national legal implementation as a process involving the implementation of international criminal law in the state in the field of domestic law with its help and in accordance with the established procedure. legal activity of state bodies aimed at the actual implementation of international obligations assumed by the state. The opinion of A.L. Luchinin that the concept of "implementation" is not synonymous with the concept of "execution", because implementation is a process, while execution is a possible result of this process.

The Council of Europe Convention for the Protection of Human Rights and Fundamental Freedoms of 1950, as well as other international treaties, the rules of which refer to the self-fulfilling, are directly applicable, they do not require the adoption of domestic legislation for their implementation. Usually, the constitutions of states contain provisions that are an example of a general reference rule, authorizing the application of international agreements binding on the state, duly ratified and published, or generally accepted principles and norms of international law, or determine the place of international acts within the legal system of a particular state.

Key words: implementation, form of influence, international criminal law, international law, national law of Ukraine. 